\title{
RNA Copy per Milliliter
}

National Cancer Institute

\section{Source}

National Cancer Institute. RNA Copy per Milliliter. NCI Thesaurus. Code C67441.

A unit of concentration of RNA copies expressed as a number of copies per unit volume equal to one milliliter. 